\title{
JURNAL HUKUM ACARA PERDATA
}

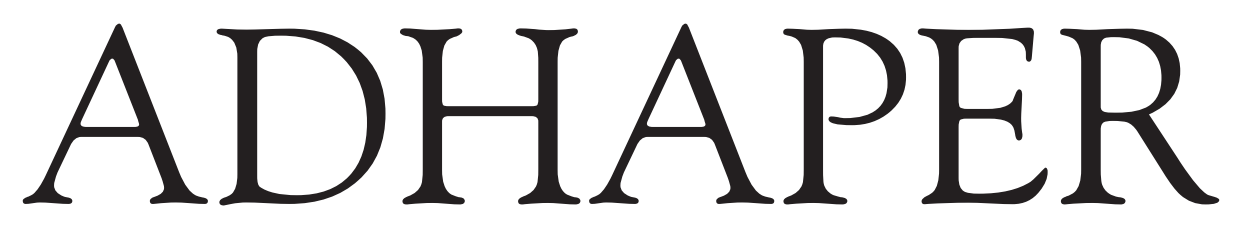

Vol. 5, No. 1, Januari - Juni 2019

- Penyelesaian Sengketa Hak atas Logo (Suatu Kajian Overlapping Hak Cipta dan Merek)

Muchtar A H Labetubun

ISSN. 2442-9090 


\section{ADHAPER}

\section{DAFTAR ISI}

1. Simplifikasi Prosedur Beracara dengan Pemanfaatan Teknologi dalam Rancangan Undang-Undang Hukum Acara Perdata

Faisal Luqman Hakim

2. Pertimbangan Hakim dalam Mengabulkan Gugatan Ganti Rugi Immateriil pada Perkara Perbuatan Melawan Hukum (Analisis Putusan Kasasi No. 3215 K/PDT/2001)

Rai Mantili, Anita Afriana.

3. Buah Simalakama Pengaturan Prosedur Mediasi di Pengadilan terhadap Penyelesaian Kepailitan Ekonomi Syariah di Indonesia

Sufiarina

4. Tuntutan atas Hak Sangkal Pemberi Kuasa Kepada Penerima Kuasa dalam Rancangan Undang-Undang Hukum Acara Perdata (Antara Ancaman dan Pengejawantahan Hak Imunitas Profesi Advokat)

Heri Hartanto

5. Pengaturan Pengajuan Gugatan oleh Otoritas Jasa Keuangan dalam Penyelesaian Sengketa Asuransi di Indonesia

Wetria Fauzi

6. Dispensasi Perkawinan di Bawah Umur dalam Perspektif Hukum Islam dan Perundang-Undangan Bidang Perkawinan di Mahkamah Syar'iyah Lhokseumawe

Teuku Yudi Afrizal

7. Hubungan Kemitraan dalam Sengketa Terkait Ketenagakerjaan

Rangga Sujud Widigda dan Aisyah Sharifa

8. Analisis Yuridis terhadap Kewajiban Hakim Perdata dalam Menilai Kompetensinya Secara Otonom

Damian Agata Yuvens dan Rianty Hutabarat

9. Penyelesaian Sengketa Hak atas Logo (Suatu Kajian Overlapping Hak Cipta dan Merek)

Muchtar A H Labetubun

10. Kewenangan Pengadilan Agama dalam Penyelesaian Sengketa Perbankan Syariah

Dhian Indah Astanti, B. Rini Heryanti, Subaidah Ratna Juita 


\title{
PENYELESAIAN SENGKETA HAK ATAS LOGO (Suatu Kajian Overlapping Hak Cipta dan Merek)
}

\author{
Muchtar AH Labetubun \\ mahlabetubun@gmail.com \\ Fakultas Hukum Universitas Pattimura, Ambon
}

\begin{abstract}
ABSTRAK
Berlakunya UndangUndang Nomor 28 tahun 2014 tentang Hak Cipta menentukan bahwa logo tidak dapat dicatatkan sebagai karya cipta, sehingga mengakibatkan karya cipta berupa logo tidak mendapatkan petikan resmi atas ciptaannya, maka perlindungan karya cipta atas suatu logo akan terancam sehingga berpontensi dibajak atau ditiru oleh orang lain. Sedangkan menurut Pasal 1 Ayat 1 Undang-Undang Nomor 20 Tahun 2016 Tentang Merek dan Indikasi Geografis bahwa, Merek adalah tanda yang dapat ditampilkan secara grafis berupa gambar, logo, nama, kata, huruf, angka, susunan warna, dalam bentuk 2 (dua) dimensi dan/atau 3 (tiga) dimensi, suara, hologram, atau kombinasi dari 2 (dua) atau lebih unsur tersebut untuk membedakan barang dan/atau jasa yang diproduksi oleh orang atau badan hukum dalam kegiatan perdagangan barang dan/atau jasa. Perbedaan pengaturan perlindungan hak atas Logo dalam Hak Cipta maupun Merek tersebut maka terjadi tumpang tindih (Overlapping) antara Hak Cipta dan Merek terkait dengan suatu karya Logo dalam praktek menghasilkan interpretasi. Penyebabnya karena kurangnya pemahaman mengenai perbedaan antara perlindungan hak cipta dan merek sehingga menimbulkan sengketa hak atas suatu Logo.
\end{abstract}

Kata Kunci: Logo, Overlapping, Penyelesaian Sengketa

\begin{abstract}
The enactment of Law Number 28 of 2014 concerning Copyright determines that the logo cannot be recorded as a copyright and so that the copyrighted work does not get official quotations from its creation, so the protection of copyrighted works on a logo will be threatened so that it is potentially hijacked or copied by others. Whereas according to Article 1 Paragraph 1 of Law Number 20 of 2016 concerning Trademarks and Geographical Indications that, Marks are signs that can be displayed graphically in the form of images, logos, names, words, letters, numbers, arrangement of colors, in the form of 2 (two) dimensions and/or 3 (three) dimensions, sounds, holograms, or a combination of 2 (two) or more of these elements to distinguish goods and/or services produced by a person or legal entity in the activity of trading goods and/or services. The difference in the arrangement of rights protection for the Logo in Copyright and Brand, the overlapping between Copyright and Brand related to a Logo work in practice results in interpretation, the reason being a lack of understanding of the differences between copyright and brand protection resulting in rights disputes on a Logo.
\end{abstract}

Keywords: Logo, Dispute Resolution, Overlapping 


\section{LATAR BELAKANG}

Ekonomi kreatif atau bisa disebut industri kreatif merupakan salah satu hal yang menjadi perhatian dalam rangka pembangunan ekonomi Indonesia. Industri kreatif merupakan industri yang berasal dari pemanfaatan kreatifitas, keterampilan serta bakat individu untuk menciptakan kesejahteraan serta lapangan pekerjaan dengan menghasilkan dan mengeksploitasi daya kreasi dan daya cipta individu tersebu. ${ }^{1}$

Praktiknya, tidak dapat dipungkiri, hak kekayaan intelektual merupakan hak yang memberikan perlindungan terhadap industri kreatif tersebut. Hak Kekayaan Intelektual (HKI) menjadi salah satu altematif dalam pembangunan ekonomi bangsa karena memiliki kontribusi ekonomi yang signifikan bagi perekonomian Indonesia, seperti menciptakan iklim bisnis yang positif, memperkuat citra dan identitas bangsa Indonesia, mendukung pemanfaatan sumber daya yang terbaru, menjadi pusat penciptaan inovasi dan pembentukan kreativitas serta dapat mencetak generasi-generasi muda yang potensial dan memiliki dampak sosial yang positif lainnya. $^{2}$

HKI adalah hak yang berasal dari hasil kegiatan kreatif suatu kemampuan daya pikir manusia yang diekspresikan kepada khalayak umum dalam berbagai bantuknya, yang memiliki manfaat serta berguna dalam menunjang kehidupan manusia, juga mempunyai nilai ekonomis. ${ }^{3}$ HKI secara umum dibagi menjadi dua kelompok besar yaitu hak cipta dan hak milik industry. Hak kekayaan intelektual yang erat kaitannya dengan merek (karena dalam beberapa hal juga besifat distinktif) adalah hak cipta. Hak Cipta merupakan hak eksklusif pencipta atau pemegang hak cipta untuk mengumumkan atau memperbanyak ciptaannya, yang timbul secara otomatis setelah suatu ciptaan dilahirkan. Perlindungan hak cipta bersifat otomatis dan timbul setelah suatu ciptaan diwujudkan dalam bentuk yang nyata (tangible form). Pendaftaran atau pencatatan hak cipta bersifat sukarela/tidak wajib kerena pendaftaran atau pencatatan tidak menimbulkan hak cipta.

Hak cipta memberikan perlindungan terhadap karya-karya cipta di bidang seni, sastra dan ilmu pengetahuan. Ciptaan yang dilindungi antara lain buku, program komputer, pamflet, lagu atau musik, rekaman suara, lukisan, gambar (logo), foto, seni ukir maupun seni kaligrafi. Namun demikian, merek dalam beberapa hal bersinggungan dengan hak cipta. Hal ini terjadi karena untuk jenis ciptaan seperti simbol, logo, foto atau gambar bisa didaftarkan sebagai hak cipta dan juga bisa sekaligus sebagai merek.

\footnotetext{
${ }^{1} \mathrm{http}: / /$ arif-danLblogspot.com/2012/01/peran-industri-kreatif-dalam.html. Diakses pada 17 Februari 2018.

$2 \mathrm{http}: / /$ andichairilfurgan.wordpress.com/tag! industri-kreatif/Diakses pada 17 Februari 2018.

${ }^{3}$ http://gigwanggu.blogspot.com!2012/05/hak-kekayaan-intelektual-haki.html, Diakses pada 17 Februari 2018.
} 
Pasal 40 Ayat (1) huruf (f) Undang-Undang Nomor 28 Tahun 2014 Tentang Hak Cipta, bahwa:

"Ciptaan yang dilindungi meliputi Ciptaan dalam bidang ilmu pengetahuan, seni, dan sastra, terdiri atas: karya seni rupa dalam segala bentuk seperti lukisan, gambar, ukiran, kaligrafi, seni pahat, patung, atau kolase".

Sedangkan Pasal 1 ayat (1) Undang-Undang Nomor 20 Tahun 2016 Tentang Merek dan Indikasi Geografis, bahwa:

"Merek adalah tanda yang dapat ditampilkan secara grafis berupa gambar, logo, nama, kata, huruf, angka, susunan warna, dalam bentuk 2 (dua) dimensi dan/atau 3 (tiga) dimensi, suara, hologram, atau kombinasi dari 2 (dua) atau lebih unsur tersebut untuk membedakan barang dan/atau jasa yang diproduksi oleh orang atau badan hukum dalam kegiatan perdagangan barang dan/atau jasa"

Dari uraian pasal tersebut bahwa, pemilikan atas merek terutama yang berbentuk logo, gambar atau sejenisnya berpotensi bermasalah di kemudian hari apabila si pemilik merek tidak mendaftarkan logo tersebut untuk mendapatkan hak atas merek dan atas hak cipta sekaligus. Bisa saja terjadi logo atau lukisan tertentu didaftarkan sebagai merek oleh seseorang sementara ada juga orang lain mendaftarkannya sebagai hak cipta.

Selain itu, kita perlu menegaskan dan memilah kedudukan Hak Cipta di satu pihak dan hak Merek di lain pihak dalam rangka memberikan perlindungan bagi Logo sebagai karya intelektual ${ }^{4}$ yang berkepastian hukum. Logo tidak hanya memiliki arti fisik dalam arti bentuk, warna atau jenis huruf yang dipakai, namun memiliki makna yang lebih mendalam karena melalui logo, maka konsumen dapat mengenali produk yang akan dibeli. Logo memiliki peran yang sangat penting dalam pengambilan keputusan konsumen dalam memilih suatu produk. Membuat sebuah logo menjadi dikenal bukan hal yang mudah, karena membutuhkan kreativitas, waktu dan dana yang tidak sedikit. Sering kita baca adanya pelaku usaha tertentu yang meniru logo atau membuat logo yang kelihatan mirip dengan pemilik logo pelaku usaha yang lain.

Tumpang tindih klaim atas logo pernah terjadi dalam perkara merek di Pengadilan Niaga Jakarta Pusat, yang melibatkan suatu yayasan perguruan tinggi swasta terkenal melawan rektor universitas tersebut. Pihak yayasan mengklaim bahwa logo perguruan tinggi tersebut telah didaftarkan sebagai merek oleh pihak yayasan dengan mendapatkan bukti sertifikat pendaftaran yang dikeluarkan Ditjen HKI. Sedangkan rektor mengklaim pihak Universitas

\footnotetext{
${ }^{4}$ Muchtar A. H Labetubun, "Perlindungan Hukum Desain Industri Di Dunia Maya (Kajian Overlaping antara Hak Cipta Dengan Hak Desain Industri)”, Bulan Oktober - Desember 2011, Volume 17, Nomor 4. Jurnal Sasi, h. 9.
} 
telah mendapatkan Sertifikat Pendaftaran Ciptaan (untuk hak cipta) juga dari Ditjen HKI atas logo yang sama

Hal ini juga terjadi dalam kasus, seperti yang diputus dalam Putusan Peninjauan Kembali Mahkamah Agung Nomor 07 PK/Pdt.Sus/2011, di mana Theng Jhing Djie selaku penerus hak, pemilik sah atas hak cipta dengan judul "Seni Lukis Logo" berdasarkan pengalihan hak dari saudara Liong Hiang Fa sesuai dengan Surat Direktur Hak Cipta Nomor H2-HC-03.02030-77/96 tanggal 1 Juni 2001 perihal pemidahan hak cipta. Kendati sudah terdaftar, akan tetapi Hadiyanto Tjukup Wirawan juga mendaftarkan dan mendapatkan dari Ditjen HKI yaitu melalui Keputusan Pemberian Hak Desain Industri berjudul "Strip Sepatu X2" dengan tanggal permohonan 29 Februari 2005. Desain industri yang dimiliki oleh Hadiyanto Tjukup Wirawan tersebut sama persis dengan Hak Cipta "Seni Lukis Logo Asics Tiger", terutama dari segi komposisi garis dan konfigurasinya.

Selain itu kasus Logo The Rolling Stones yang di cetak di kaos. The Rolling Stones merupakan band yang terkenal baik didalam negeri maupun mancanegara. The Rolling Stones merupakan bagian dari British Invasion yang populer di era 60 -an, bersama sesama band asal Inggris The Beatles. Band yang beranggotakan Mick Jagger, Keith Richards, Ronnie Wood, dan Charlie Watts ini menganut genre Rock, blues, blues rock, rhythm and blues, rock and roll. The Rolling Stones sendiri disebut-sebut sebagai salah satu grup band terbesar di dunia sepanjang masa hingga sekarang yang menghasilkan banyak single dan lagu yang menjadi hits rock internasional

Atas nama penghematan, pelaku usaha/perusahaan, seringkali mengabaikan pendaftaran hak cipta. Padahal biaya pendaftaan hak cipta tidak mahal. Tentu ini suatu penghematan berisiko tinggi, apabila dikaitkan dengan potensi dualisme kepemilikan merek yang hendak didaftarkan seperti contoh kasus yang diuraikan diatas, untuk mengantisipasi hal seperti di atas, sudah seharusnya suatu logo, gambar, foto atau karya seni lainnya yang hendak digunakan sebagai merek, selain diajukan pendaftrannya untuk mendapatkan hak atas merek juga didaftarkan pula sebagai hak Cipta, karena kalau sudah terjadi sengketa, akan selalu sulit diselesaikan dan merugikan para pihak yang bersengketa terutama pemilik/penemu merek maupun ciptaannya yang sudah melekat di hati konsumen dan telah merupakan kekayaan bernilai tinggi

\section{PEMBAHASAN}

\section{Urgensi Perlindungan Hak atas Logo}

Perlindungan hukum erat kaitannya dengan konsep pembentukan negara. Negara merupakan organisasi kekuasaan yang eksistensinya dipahami sebagai hasil bentukan 
masyarakat melalui perjanjian sosial antar warga masyarakat. Keberadaan negara merupakan kebutuhan bersama untuk melindungi dan memenuhi hak-hak individu warga negara serta menjaga tertib kehidupan sosial bersama. ${ }^{5}$

Upaya perlindungan sejalan pula dengan peran negara dalam mewujudkan cita hukum Indonesia yang dirumuskan sebagai berikut: ${ }^{6}$

a) Negara melindungi segenap bangsa Indonesia dan seluruh tumpah darah Indonesia dengan berdasarkan atas persatuan;

b) Negara hendak mewujudkan keadilan sosial bagi seluruh tumpah darah Indonesia dengan berdasarkan atas persatuan;

c) Negara yang berkedaulatan rakyat, berdasar kerakyatan dan permusyawaratan perwakilan; dan

d) Negara berdasar atas Ketuhanan Yang Maha Esa menurut dasar kemanusiaan yang adil dan beradab.

Sejak adanya pengaturan tentang hak cipta 3 (tiga) abad yang lalu, hak cipta sudah menjadi bagian dari industri kreatif yang tidak ingin karyanya dibajak, ditiru, atau diplagiasi orang lain. Pada awalnya, hak cipta hanya menyentuh ranah karya tulis. Upaya untuk melindungi hak cipta tersebut adalah untuk menghindari dari duplikasi pihak lain yang tidak bertanggungjawab. Pada saat itu, duplikasi atas karya orang lain tanpa ijin marak dilakukan, baik untuk kepentingan komersil maupun kepentingan komedi. ${ }^{7}$ Seiring berjalannya waktu, hak cipta kemudian berkembang dengan mencakup ranah lain, termasuk musik dan juga logo.

Setiap negara menerapkan peraturan sendiri mengenai hak cipta. Perlindungan hak cipta di Indonesia talah dimulai sejak jaman Hindia Belanda dengan berlakunya Auteurswet 1912 Stbl. 600/1912. Sejalan dengan berlakunya UUD 1945, masa berlaku Auteurswet 1912 Stbl. 600/1912 tetap dipertahankan sampai terbitnya UU No. 6 tahun 1982 tentang hak cipta yang kemudian diubah menjadi UU No. 7 tahun 1987. Sepuluh tahun kemudian, UU tersebut diperbaharui lagi menjadi UU No. 12 tahun 1997, kemudian diperbaharui lagi menjadi UU No. 19 tahun 2002. Perubahan terakhir yang berlaku sampai saat ini adalah lahirnya UU No. 28 tahun 2014 yang menggantikan UU No. 19 tahun 2002 tentang hak cipta. ${ }^{8}$ UU No. 28 tahun 2014 tentang hak cipta merupakan ketentuan bagi perkembangan hak cipta karena banyak perubahan dalam Undang-Undang yang baru tersebut.

\footnotetext{
${ }^{5}$ Penegakan Hukum dan Tata Kelola Pemerintahan Yang Baik, www.mahfudmd.com, Diakses pada 17 Februari 2018.

${ }^{6}$ Yoan Nursari Simanjuntak, 2005, Hak Desain Industri (Sebuah Realitas Hukum dan Sosial), Srikandi, Surabaya, h. $214-215$.

${ }^{7}$ Paul Goldstein, 1997, Hak Cipta: Dahulu, Kini dan Esok, YOI, Jakarta, h. 1-2

${ }^{8}$ Tim Visi Media, Panduan Resmi Hak Cipta, Visi Media, Jakarta, 2015, h. xi
} 
Dalam praktiknya sering ditemukan adanya kasus hak cipta yang sebenarnya merupakan sengketa merek. hak cipta dan merek pada dasarnya merupakan perlindungan kekayaan intelektual yang berbeda. Namun perbedaan tersebut terkadang menjadi kabur ketika membicarakan kekayaaan intelektual berupa logo yang didaftarkan sebagai merek. Dalam sebuah jurnal hak kekayaan intelektual, terkait persinggungan antara hak cipta dan merek, Agus Sardjono memberikan gambaran kasus yang rentan terhadap persinggungan tersebut sebagai berikut: ${ }^{9}$

"A sebuah perusahaan memesan logo dari seseorang bernama B. Kemudian setelah B selesai membuat logo tersebut, kita asumsikan logo tersebut merupakan Ciptaan atau dengan kata lain gambar yang dilindungi hak cipta berdasarkan Pasal 12 ayat (1) f Undang-Undang No. 19 Tahun 2002 Tentang Hak Cipta. Karena logo tersebut merupakan Ciptaan, B dapat disebut sebagai Pencipta berdasarkan Undang-Undang No. 19 Tahun 2002 Tentang Hak Cipta. A kemudian mendaftarkan logo tersebut ke Direktorat Hak Cipta, DJHKI. Berdasarkan peraturan perundang-undangan yang ada, Direktorat Hak Cipta biasanya akan menerima pendaftaran itu, meskipun dalam ranah perlindungan hak cipta, pendaftaran bukanlah syarat untuk adanya perlindungan hak cipta. A sebagai pihak yang melakukan pendaftaran itu kemudian memperoleh kualifikasi sebagai pemegang hak cipta atas logo tersebut.

Selanjutnya karena niat perusahaan itu ketika memesan logo adalah memang untuk untuk menjadikannya sebagai merek, maka A kemudian mendaftarkan logo tersebut ke Direktorat Merek. Setelah terdaftar, logo itu dilekatkan pada sebuah produk. Perlindungan manakah yang berlaku terhadap logo tersebut ? hak cipta ataukah merek ? Apakah keduanya dapat diberlakukan secara bersamaan apabila terjadi sengketa terhadap logo tersebut ? Sebelum menjawab pertanyaan tersebut mari kita lihat beberapa komentar yang khusus membahas mengenai perbedaan antara hak cipta dan merek.

Berikut beberapa definisi yang perlu diperhatikan dalam memahami perbedaaan antara perlindungan hak cipta dan merek:

Pasal 1 angka (1) UU 28 2014, bahwa:

"Hak Cipta adalah hak eksklusif pencipta yang timbul secara otomatis berdasarkan prinsip deklaratif setelah suatu ciptaan diwujudkan dalam bentuk nyata tanpa mengurangi pembatasan sesuai dengan ketentuan peraturan perundangundangan."

\footnotetext{
${ }^{9}$ Agus Sardjono, “Titik Singgung Perlindungan HKI: Hak Cipta, Merek, dan Desain Industri”, 2012, Volume 1, Nomor 1, Jurnal Hak Kekayaan Intelektual, h. 32.
} 
Pasal 1 angka (3) UU 28 2014, bahwa:

"Ciptaan adalah setiap hasil karya cipta di bidang ilmu pengetahuan, seni, dan sastra yang dihasilkan atas inspirasi, kemampuan, pikiran, imajinasi, kecekatan, keterampilan, atau keahlian yang diekspresikan dalam bentuk nyata".

Pasal 1 angka (1) UU Merek dan IG No 20 2016, bahwa:

"Merek adalah tanda yang dapat ditampilkan secara grafis berupa gambar, logo, nama, kata, huruf, angka, susunan warna, dalam bentuk 2 (dua) dimensi dan/atau 3 (tiga) dimensi, suara, hologram, atau kombinasi dari 2 (dua) atau lebih unsur tersebut untuk membedakan barang dan/atau jasa yang diproduksi oleh orang atau badan hukum dalam kegiatan perdagangan barang dan/atau jasa".

Pasal 1 angka (2) UU Merek dan IG No 20 2016, bahwa:

"Merek Dagang adalah Merek yang digunakan pada barang yang diperdagangkan oleh seseorang atau beberapa orang secara bersama-sama atau badan hukum untuk membedakan dengan barang sejenis lainnya”.

Dari definisi-definisi tersebut dapat disimak beberapa clue yang sesungguhnya dan seharusnya mendasari penafsiran tentang subject matter dari tiap-tiap peraturan di atas. Beberapa hal berikut adalah analisis tentang clue yang dimaksud: ${ }^{10}$

1) Perlindungan hak cipta hanya diterapkan dalam kaitannya dengan komersialisasi ciptaannya (the works). Dengan demikian, yang menjadi objek adalah ciptaan (works) itu sendiri yang dikomersialkan melalui perbanyakan atau pengumuman, bukan produk yang ada di dalam kemasan atau barang-barang (produk) yang dibuat berdasarkan pola desain tertentu.

2) Kemasan biasanya digunakan sebagai penanda (merek) dari produk yang dikemas. Dengan demikian, komersialisasinya dilakukan bukan terhadap kemasannya, melainkan atas produknya. Contoh: produknya adalah kacang. Kacang itu dikemas di dalam plastik, karton, atau kertas yang diberi gambar dan tanda-tanda lainnya. Meskipun gambar pada kemasan tentu saja diciptakan oleh seseorang, tetapi gambar itu sendiri tidak dimaksudkan sebagai produknya, melainkan sebagai identitas produk atau untuk mengidentifikasi suatu produk dari produk lainnya yang sejenis. Itu sebabnya dipersyaratkan adanya daya pembeda (distinctiveness). Di sinilah domain hukum merek.

3) Ciptaan (works) yang dimaksud dalam konteks perlindungan hak cipta adalah ciptaan dalam lapangan ilmu pengetahuan, seni, atau sastra. WIPO IP Handbook dengan jelas

${ }^{10} \mathrm{Ibid}$, h. 29-31. 
menyebutkan bahwa "Copyright protection is above all one of the means of promoting, enriching, and disseminating the national cultural heritage". Dengan demikian, ada kualitas tertentu dari ciptaan (bersifat kultural), yang tentunya tidak dimaksudkan sebagai tanda merek (mark), dan bukan pula sebagai pola (pattern). Ciptaan dibuat dalam kaitannya dengan ilmu pengetahuan (misal: text book), seni (musik, lukisan, atau patung), atau sastra (puisi, novel, dsb).

\section{Tumpang Tindih Perlindungan Hak atas Logo: Antara Hak Cipta atau Merek}

Pemilikan atas merek terutama yang berbentuk logo, gambar atau sejenisnya, berpotensi bermasalah di kemudian hari apabila pemilik merek tidak mendaftarkan logo tersebut untuk mendapatkan hak atas merek dan atas hak cipta sekaligus. Bisa saja terjadi logo atau lukisan tertentu didaftarkan sebagai merek oleh seseorang sementara ada juga orang lain mendaftarkannya sebagai hak cipta.

Tumpang tindih klaim atas logo yang terjadi dalam perkara merek di Pengadilan Niaga, menandakan bahwa kepemilikan suatu logo sebagaimana yang diuraikan diatas berpotensi atas dualisme hak atas logo, hal ini disebabkan karena perbedaan proses pendaftaran yang berbeda. Pemeriksaan substantif tidak dikenal dalam proses pendaftaran hak cipta, sehingga ciptaan tersebut mendapatkan sertifikat dengan mudah. Pendaftaran hak cipta juga dipermudah karena dalam konsep hukum hak cipta, pendaftaran tidak menimbulkan hak. Hal ini berbeda dengan merek karena menganut istilah first to file principle dimana pihak yang pertama kali mendaftarkan diakui sebagai pemegang hak merek atas merek.

Disamping itu, merek yang bisa didaftar adalah yang memenuhi syarat-syarat tertentu, tidak semua pemohonan atas merek dapat didaftarkan, misalnya karena permohonan yang diajukan pemohon beritikad tidak baik. Pemohon dianggap beritikad tidak baik apabila pemohon merek tersebut tidak jujur, karena ada niat tersembunyi untuk meniru atau membonceng ketenaran merek orang lain.

Sebaliknya, persyaratan mendaftarkan ciptaan tidak serumit pendaftaran merek sehingga lebih gampang mendapatkannya, ini adalah suatu dilema yang cukup sulit diatasi, terutama bila terjadi dualise kepemilikan, Dalam prakteknya selama ini, para pelaku usaha cenderung menekankan pada pendaftaran merek dan mengabaikan aspek hak cipta atas suatu merek yang hendak didaftar. Atas nama penghematan, pelaku usaha/perusahaan, seringkali mengabaikan pendaftaran hak cipta. Padahal biaya pendaftaan hak cipta tidak mahal. Tentu ini suatu penghematan berisiko tinggi, apabila dikaitkan dengan potensi dualisme kepemilikan merek yang hendak didaftarkan.

Mengantisipasi hal seperti di atas, sudah seharusnya suatu logo, gambar, foto atau karya seni lainnya yang hendak digunakan sebagai merek, selain diajukan pendaftrannya untuk 
mendapatkan hak atas merek juga didaftarkan pula sebagai hak Cipta, karena kalau sudah terjadi sengketa, akan selalu sulit diselesaikan dan merugikan para pihak yang bersengketa terutama sipemilik/penemu merek maupun ciptaannya yang sudah melekat di hati konsumen dan telah merupakan kekayaan bernilai tinggi.

\section{Penyelesaian Sengketa Hak Atas Logo}

Sengketa hak atas Logo dalam konteks pengaturan Pasal 65 UU No. 28 tahun 2014 berpotensi menimbulkan banyak sengketa. Hal ini karena ciptaan berupa logo yang dilindungi ternyata tidak dapat dicatatkan di Kementerian Hukum dan HAM. Banyaknya logo yang tidak dicatatkan dan tidak terdaftar akan mengakibatkan banyaknya sengketa logo. Dapat dibayangkan, untuk hak cipta yang sudah dicatatkan saja masih berpotensi menimbulkan sengketa, apalagi logo yang tidak dicatatkan.

Penyelesaian sengketa terhadap tindakan peniruan/pemalsuan, sebagaimana yang kita ketahui bahwa penyelesaian sengketa bisa melalui jalur non litigasi dan jalur litigasi. ${ }^{11}$

\section{a. Penyelesaian Sengketa Di Luar Pengadilan}

Penyelesaian sengketa di luar Pengadilan dapat dilakukan dengan menggunakan alternatif penyelesaian sengketa yaitu mediasi, negosiasi, konsiliasi dan arbitrase. Sengketa yang dapat diselesaikan adalah sengketa yang dijelaskan dalam Pasal 93 UU No. 20 Tahun 2016 bahwa "Selain penyelesaian gugatan sebagaimana dimaksud dalam Pasal 83 para pihak dapat menyelesaikan sengketa melalui arbitrase atau alternatif penyelesaian sengketa", dan Penjelasan Pasal 95 ayat (1) UU No. 28 tahun 2014, yakni:

1) Arbitrase

Mengacu kepada Undang-Undang Nomor 30 Tahun 1999 tentang Arbitrase dan Alternatif Penyelesaian Sengketa (selanjutnya disingkat UUAAPS) pengertian arbitrase sebagai berikut "Arbitrase adalah cara penyelesaian suatu sengketa perdata di luar peradilan umum yang didasarkan pada perjanjian arbitrase yang dibuat secara tertulis oleh para pihak yang bersengketa". Ketentuan Acara dalam proses arbitrase diatur dalam Pasal 27, 28, 29, 30, Undang- Undang nomor 30 tahun 1999 tentang Arbitrase dan Alternatif Penyelesaian Sengketa.

Hasil dari arbitrase adalah putusan. Hal tersebut sebagaimana diatur dalam Pasal 54 Undang-Undang Nomor 30 tahun 1999 tentang Arbitrase dan Alternatif Penyelesaian Sengketa:

\footnotetext{
${ }^{11}$ Muchtar A H Labetubun, “Aspek Hukum Perlindungan Desain Industri kerajinan Kerang Mutiara Dalam Pemberdayaan Usaha Kecil Di Kota Ambon”, Bulan April - Juni 2011, Volume 17 Nomor 2, Jurnal Sasi, h. 33.
} 
Pasal 54:

(1) Putusan arbitrase harus memuat:

a) Kepala putusan yang berbunyi "Demi Keadilan Berdasarkan Ketuhanan Yang Maha Esa";

b) Nama lengkap dan alamat para pihak;

c) Uraian singkat sengketa;

d) Pendirian para pihak;

e) Nama lengkap dan alamat arbiter;

f) pertimbangan dan kesimpulan arbiter atau majelis arbitrase mengenai keseluruhan sengketa;

g) pendapat tiap-tiap arbiter dalam hal terdapat perbedaan pendapat dalam majelis arbitrase;

h) amar putusan;

i) tempat dan tanggal putusan; dan

j) tanda tangan arbiter atau majelis arbitrase.

2) Mediasi

Dalam Pasal 1 ayat (6) Peraturan Mahkamah Agung Nomor 2 Tahun 2003 tentang Prosedur Mediasi di Pengadilan, yang mengartikan mediasi sebagai berikut "Mediasi adalah penyelesaian sengketa melalui proses perundingan para pihak dengan dibantu oleh mediator".

3) Negosiasi

Negosiasi merupakan bagian dari mekanisme penyelesaian sengketa di antara para pihak dengan jalan damai, yaitu melalui suatu perundingan. ${ }^{12}$

4) Konsiliasi

Pengertian konsiliasi dapat ditemukan dalam pasal 1 ayat (10) dan alinea 9 Penjelasan Umum UUAAPS, yaitu konsiliasi merupakan salah satu lembaga alternatif dalam penyelesaian sengketa. Dengan demikian, maka konsiliasi merupakan proses penyelesaian sengketa alternatif dan melibatkan pihak ketiga yang diikutsertakan untuk menyelesaikan sengketa.

Jika melihat ketentuan yang terdapat dalam UUAAPS, maka alternatif penyelesaian sengketa tidak hanya terbatas pada mediasi, negosiasi, atau konsiliasi, dan arbitrase. Pasal 1 ayat (10) UUAAPS menentukan bahwa “Alternatif Penyelesaian Sengketa adalah lembaga penyelesaian sengketa atau beda pendapat melalui prosedur yang disepakati para pihak, yakni

\footnotetext{
12 Idris Talib, "Bentuk Putusan Penyelesaian Sengketa Berdasarkan Mediasi”, 2013, Volume I, Nomor 1 Jan-Mrt, Jurnal Lex et Societatis, h. 22.
} 
penyelesaian di luar pengadilan dengan cara konsultasi, negosiasi, mediasi, konsiliasi, atau penilaian ahli". Terbatasnya penyelesaian di luar pengadilan tersebut tentunya juga membatasi proses penyelesaian di luar pengadilan sebagai salah satu penyelesaian sengketa yang saat ini lebih gencar dilakukan. Semestinya penyelesaian di luar pengadilan juga digencarkan dan diupayakan dengan sungguh-sungguh, supaya permasalahan bisa diselesaikan dengan kekeluargaan.

Hasil dari konsultasi, negosiasi, mediasi, konsiliasi, atau penilaian ahli adalah kesepakatan. Pelaksanaan alternatif penyelesaian sengketa tersebut dilakukan sesuai dengan ketentuan dalam Pasal 6 Undang-Undang nomor 30 tahun 1999 tentang Arbitrase dan Alternatif Penyelesaian Sengketa: Pasal 6, bahwa:

(1) Sengketa atau beda pendapat perdata dapat diselesaikan oleh para pihak melalui alternatif penyelesaian sengketa yang didasarkan pada itikad baik dengan mengesampingkan penyelesaian secara litigasi di Pengadilan Negeri.

(2) Penyelesaian sengketa atau beda pendapat melalui alternatif penyelesaian sengketa sebagaimana dimaksud dalam ayat (1) diselesaikan dalam pertemuan langsung oleh para pihak dalam waktu paling lama 14 (empat belas) hari dan hasilnya dituangkan dalam suatu kesepakatan tertulis.

(3) Dalam hal sengketa atau beda pendapat sebagaimana dimaksud dalam ayat (2) tidak dapat diselesaikan, maka atas kesepakatan tertulis para pihak,sengketa atau beda pendapat diselesaikan melalui bantuan seorang atau lebih penasehat ahli maupun melalui seorang mediator.

(4) Apabila para pihak tsb dalam waktu paling lama 14 (empat belas) hari dengan bantuan seorang atau lebih penasehat ahli maupun melalui seorang mediator tidak berhasil mencapai kata sepakat, atau mediator tidak berhasil mempertemukan kedua belah pihak, maka para pihak dapat menghubungi sebuah lembaga arbitrase atau lembaga alternatif penyelesaian sengketa untuk menunjuk seorang mediator.

(5) Setelah penunjukan mediator oleh lembaga arbitrase atau lembaga alternatif penyelesaian sengketa, dalam waktu paling lama 7 (tujuh) hari usaha mediasi harus sudah dapat dimulai.

(6) Usaha penyelesaian sengketa atau beda pendapat melalui mediasi sebagaimana dimaksud dalam ayat (5) dengan memegang teguh kerahasiaan, dalam waktu paling lama 30 (tiga puluh) hari harus tercapai kesepakatan dalam bentuk tertulis yang ditandatangani oleh semua pihak yang terkait. 
(7) Kesepakatan penyelesaian sengketa atau beda pendapat secara tertulis adalah final dan mengikat para pihak untuk dilaksanakan dengan itikad baik serta wajib didaftarkan di Pengadilan Negeri dalam waktu paling lama 30 (tigapuluh) hari sejak penandatanganan.

(8) Kesepakatan penyelesaian sengketa atau beda pendapat sebagaimana dimaksud dalam ayat (7) wajib selesai dilaksanakan dalam waktu paling lama 30 (tiga puluh) hari sejak pendaftaran.

(9) Apabila usaha perdamaian sebagaimana dimaksud dalam ayat (1) sampai dengan ayat (6) tidak dapat dicapai, maka para pihak berdasarkan kesepakatan secara tertulis dapat mengajukan usaha penyelesaiannya melalui lembaga arbitrase atau arbitrase ad-hoc.

Berdasarkan beberapa bentuk alternatif penyelesaian sengketa sebagaimana telah diuraikan di atas, bentuk negosiasi dapat dikatakan bentuk yang sederhana dan dapat dimanfaatkan dalam upaya menyelesaikan sengketa, karena berjalan di atas prinsip musyawarah untuk mufakat diantara para pihak yang bersengketa. Negosiasi merupakan proses komunikasi 2 (dua) arah yang dirancang untuk mencapai kesepakatan pada saat kedua belah pihak memiliki kepentingan yang sama maupun berbeda, tanpa melibatkan pihak ketiga sebagai penengah. Negosiasi, adalah istilah lain dari musyawarah untuk mufakat.

Dasar utama dari hak cipta sebagai konsep kepemilikan yaitu bahwa hal tersebut memungkinkan adanya perlindungan bagi hasil karyanya sendiri. Hal ini merupakan dasar ketentuan, di mana karya-karya tersebut merupakan ekspresi dari gagasan yang diperkenalkan kepada publik. Para pemilik tersebut menjadi bagian dari hadirnya berbagai informasi dimana arus informasi yang tanpa hambatan tersebut akan dapat menjadi penting bagi masyarakat secara umum. Oleh karena itu, hak cipta memberikan jaminan bahwa para pencipta tidak hanya menjaga hasil karyanya di bawah pengawasan, dengan jalan mencegah terjadinya penyalinan ulang tanpa izin, akan tetapi juga memberikan jaminan bahwa para pencipta dapat memperoleh hasil manfaat dari hasil pekerjaan intelektualnya tersebut. Hal ini dapat dianggap sebagai sebuah insentif untuk mempublikasikan karyanya. Hak cipta juga bekerja sebagai sebuah kompensasi atas resiko keuangan dari penerimaan sang pemilik dengan jalan mempublikasikan hasik karyanya.

Tanpa adanya perlindungan akan hak cipta, seorang pencipta mungkin saja akan menolak untuk mempublikasikan hasil karyanya, yang pada akhirnya publik juga tidak dapat menikmati karya tersebut. Keuntungan yang dinikmati oleh pencipta melalui perlindungan akan hak cipta merupakan hal yang problematik. Hak penuh yang berada pada pemilik terhadap siapapun yang ingin menyalin hasil karyanya terkadang sangat berlawanan dengan kepentingan publik, seperti 
misalnya pada peran dan kepentingan di bidang sosial, politik, pendidikan dan kebudayan. Sebagian mengatakan bahwa informasi dan hasil karya seharusnya dipertimbangkan sebagai benda umum, oleh karenya tidak perlu dilindungi lagi oleh Undang Undang Nomor 28 Tahun 2014 tentang Hak Cipta. Hak untuk mengontrol akses bagi hasil karya seseorang sebelum dipublikasikan tidak akan menimbulkan permasalahan dalam kebebasan berbicara, akan tetapi penerbit dapat mengontrol akses tersebut setelah terjadinya publikasi. Hal ini menjelaskan kenapa secara historis hak cipta dianggap sebagai suatu bentuk monopoli yang seharusnya secara tegas ditafsirkan untuk melayani kepentingan publik di atas pemegang hak cipta.

\section{b. Penyelesaian Sengketa di Pengadilan}

Penyelesaian di Pengadilan dapat dilakukan untuk memutuskan ganti rugi yang akan diterima oleh pihak yang merasa dirugikan. Hal tersebut sebagaimana diatur dalam Pasal 96 UU No. 28 tahun 2014. Proses pengajuan gugatan ke Pengadilan dilakukan dengan berpedoman kepada tahapan yang sudah diatur dalam Pasal 100 UU No. 28 tahun 2014 dan tahap penyelesaian akan dilaksanakan maksimal 90 (sembilan puluh) hari dan dapat ditambahkan maksimal 30 (tiga puluh) hari sebagaimana dalam Pasal 101 UU No. 28 tahun 2014.

Penyelesaian sengketa melalui pengadilan dapat dilakukan dengan cara mengajukan gugatan perdata melalui pengadilan yang berwenang, jika sengketa tersebut menyangkut pelanggaran hak cipta maupun merek, maka gugatan diajukan ke Pengadilan Niaga. Sebagaimana disebutkan dalam ketentuan Pasal 83-86 UU No. 20 Tahun 2016 dan Pasal 95 Undang-Undang Nomor 28 tahun 2014 tentang Hak Cipta:

1) Penyelesaian sengketa Hak Cipta dapat dilakukan melalui alternatif penyelesaian sengketa, arbitrase, atau pengadilan.

2) Pengadilan yang berwenang sebagaimana dimaksud ayat (1) adalah Pengadilan Niaga.

3) Pengadilan lainnya selain Pengadilan Niaga sebagaimana dimaksud ayat (1) tidak berwenang menangani penyelesaian sengketa Hak Cipta.

4) Selain pelanggaran Hak Cipta dan/atau Hak Terkait dalam bentuk Pembajakan, sepanjang para pihak yang bersengketa diketahui. keberadaannya dan/atau berada di wilayah Negara Kesatuan Republik Indonesia harus menempuh terlebih dahulu penyelesaian sengketa melalui mediasi sebelum melakukan tuntutan pidana.

Dalam gugatan pelanggaran hak cipta dikenal penetapan sementara (injunction) sebagaimana diatur dalam Pasal 106 Undang-Undang Hak Cipta. Penetapan ini dikeluarkan oleh Pengadilan Niaga atas permintaan dari pihak yang haknya dilanggar. Penetapan Sementara 
dikeluarkan antara lain untuk mencegah berlanjutnya pelanggaran dan masuknya barang yang diduga melanggar Hak Cipta dan Hak Terkait ke jalur perdagangan termasuk tindakan eksportasi dan importasi. ${ }^{13}$ Pengadilan Niaga dapat mengeluarkan penetapan sementara untuk:

a) Mencegah masuknya barang yang diduga hasil pelanggaran Hak Cipta atau Hak Terkait ke jalur perdagangan;

b) Menarik dari peredaran dan menyita serta menyimpan sebagai alat bukti yang berkaitan dengan pelanggaran Hak Cipta atau Hak Terkait tersebut;

c) Mengamankan barang bukti dan mencegah penghilangannya oleh pelanggar; dan/ atau

d) Menghentikan pelanggaran guna mencegah kerugian yang lebih besar. ${ }^{14}$

Perlindungan hukum merupakan upaya yang diatur oleh Undang-Undang guna mencegah terjadinya pelanggaran Hak Cipta maupun merek terhadap logo yang dibajak. Jika terjadi pelanggaran, maka pelanggar tersebut harus diproses secara hukum dan bila terbukti melakukan pelanggaran akan dijatuhi hukuman sesuai dengan ketentuan Undang-Undang Hak Cipta. Hak untuk mengajukan gugatan keperdataan atas pelanggaran Hak Cipta dan atau Hak Terkait tidak mengurangi Hak Pencipta dan atau Pemilik Hak Terkait untuk menuntut secara pidana. ${ }^{15}$

Pada dasarnya dengan adanya perlindungan hukum terhadap hak cipta dan merek, berarti hak dan kepentingan pencipta diakui dan dilindungi oleh Undang-Undang, sehingga mereka dapat menuntut setiap orang yang melanggar hak dan kepentingannya atas karya cipta maupun merek tersebut. Upaya hukum untuk menuntut para pelanggar hak cipta dan merek dapat dilakukan oleh pencipta atau organisasi yang terkait dengan ciptaan/merek tersebut, melalui tuntutan pidana atau gugatan secara perdata.

Pada proses penyelesaian sengketa di Pengadilan, para pihak dapat meminta pengadilan untuk mengeluarkan penetapan sementara. Hal-hal yang dapat dimintai penetapan tersebut adalah untuk hal-hal sebagaimana diatur dalam Pasal 94 UU No. 20 Tahun 2016 dan Pasal 106 UU No. 28 tahun 2014. Ketentuan yang menjadi permasalahan yuridis dalam permintaan penetapan di Pengadilan adalah terkait dengan persyaratan yang harus dipenuhi. Di antara syarat yang harus dipenuhi adalah melampirkan bukti kepemilikan hak cipta.

Pembuktian tersebut sulit dilakukan oleh pihak yang merasa dirugikan. Hal ini karena pihak yang merasa dirugikan tidak mempunyai petikan pemegang hak, karena tidak boleh

\footnotetext{
${ }^{13}$ Lihat Pasal 106 huruf d Undang Undang Nomor 28 Tahun 2014 tentang Hak Cipta

${ }^{14}$ Lihat Pasal 106 Undang Undang Nomor 28 Tahun 2014 tentang Hak Cipta

${ }^{15}$ Lihat Pasal 105 Undang Undang Nomor 28 Tahun 2014 tentang Hak Cipta
} 
dicatatkan. Bukti apa yang harus ditunjukkan juga tidak jelas. Peraturan perundang-undangan ini tidak menyediakan solusi terkait pembuktian kepemilikan hak cipta logo yang tidak bisa dicatatkan.

\section{PENUTUP}

Secara umum kata "Logo" dilihat dari aspek hak cipta dengan merek ada kesamaan, hal ini dapat dikatakan bahwa kurangnya pemahaman mengenai perbedaan antara perlindungan Hak Cipta dan Merek menyebabkan munculnya sengketa Hak Cipta yang sesungguhnya merupakan sengketa Merek. Pada dasarnya Perlindungan Hak Cipta hanya diterapkan dalam kaitannya dengan komersialisasi Ciptaan. Ciptaan yang dimaksud dalam konteks perlindungan Hak Cipta adalah karya yang memiliki sifat khas dan pribadi yang menunjukan keasliannya dalam lapangan ilmu pengetahuan, seni, atau sastra. Dengan demikian yang menjadi objek adalah Ciptaan itu sendiri yang dikomersialkan melalui perbanyakan atau pengumuman. Sedangkan perlindungan Merek pada dasarnya bertujuan melindungi produk, baik itu berupa barang ataupun jasa, dari asosiasi yang keliru terkait sumber dari produk tersebut yang kemudian akan melindungi produsen maupun konsumen atas produk yang bersangkutan.

\section{DAFTAR BACAAN}

\section{Buku}

Goldstein, Paul. 1997, Hak Cipta: Dahulu, Kini dan Esok, YOI, Jakarta.

Media, Tim Visi. 2015, Panduan Resmi Hak Cipta, Visi Media, Jakarta.

Simanjuntak, Yoan Nursari. 2005, Hak Desain Industri (Sebuah Realitas Hukum dan Sosial), Srikandi, Surabaya

\section{Jurnal}

Sardjono, Agus. “Titik Singgung Perlindungan HKI: Hak Cipta, Merek, dan Desain Industri”, 2012, Volume 1, Nomor 1, Jurnal Hak Kekayaan Intelektual.

Talib, Idris. "Bentuk Putusan Penyelesaian Sengketa Berdasarkan Mediasi”, 2013, Volume I, Nomor 1 Jan-Mrt, Jurnal Lex et Societatis.

Labetubun, Muchtar A H. “Aspek Hukum Perlindungan Desain Industri kerajinan Kerang Mutiara Dalam Pemberdayaan Usaha Kecil Di Kota Ambon”, Bulan April - Juni 2011, Volume 17 Nomor 2, Jurnal Sasi. 
Labetubun, Muchtar A. H. "Perlindungan Hukum Desain Industri Di Dunia Maya (Kajian Overlaping antara Hak Cipta Dengan Hak Desain Industri)”, Bulan Oktober - Desember 2011, Volume 17, Nomor 4. Jurnal Sasi.

\section{Peraturan Perundang-Undangan}

Undang Undang Nomor 28 Tahun 2014 Tentang Hak Cipta.

Undang Undang Nomor 20 Tahun 2016 Tentang Merek dan Indikasi Geograf

\section{Sumber Lain}

Penegakan Hukum dan Tata Kelola Pemerintahan Yang Baik, www.mahfudmd.com, Diakses pada 17 Februari 2018.

http://arif-danLblogspot.com/2012/01/peran-industri-kreatif-dalam.html. Diakses pada 17 Februari 2018.

http://andichairilfurgan.wordpress.com/tag!industri-kreatif/Diakses pada 17 Februari 2018. http://gigwanggu.blogspot.com!2012/05/hak-kekayaan-intelektual-haki.html, Diakses pada 17 Februari 2018. 